Silvana VRANIĆ

UDK 272-282.7:003.349.1

Filozofski fakultet u Rijeci

$811.163 .42 ’ 282$

Rijeka

Izvorni znanstveni članak

silvana.vranic@uniri.hr

Primljen: 25. svibnja 2019.

Prihvaćen: 9. listopada 2019.

\title{
JEZIČNE ZNAČAJKE TEMPORALA \\ DRUGOGA BERAMSKOGA (LJUBLJANSKOGA) BREVIJARA S GLEDIŠTA POVIJESNE DIJALEKTOLOGIJE ${ }^{1}$
}

U ovom su radu istaknute značajke temporala Drugoga beramskoga (ljubljanskoga) brevijara $\left(\mathrm{BrBer}_{2}\right)$ koje se razlikuju od hrvatskih crkvenoslavenskih značajki, a koje bi se mogle pripisati vernakularu. Dosadašnji pokušaji utvrđivanja vernakularnih elemenata na prvih 50 listova s aspekta dijakronijske dijalektologije pokazuju da taj dio temporala $\mathrm{BrBer}_{2}$ pripada sjevernomu tipu liturgijskih tekstova. Razlog je takvomu zaključku u prvom redu brojnost $z \check{z}$-refleksa jotacije dentala $d$ (ाъ) iako je na dijelu 38ra-50ra ipak rjeđe zastupljen, što pridonosi pretpostavci da je potonji dio pisala druga ruka. Premda su prvih 30 (odnosno prvih 20, pa 21-30) listova, kao što je odredio M. Žagar na temelju osnovnoga dojma pisma (prema slovnim proporcijama, smještaju u retku), pisala dva pisara - prema udjelu su vernakularnih značajki i stranice od 30cd do 37cd bez bitnih različitosti, što govori ili o pripadnosti pisara istoj pisarskoj školi ili o zajedničkomu materinskom govoru. Vodeći računa o (ne)pouzdanosti starih tekstova kao dijalektoloških predložaka, jednakom se je metodologijom - dijakronijske ili povijesne dijalektologije - pokušalo u ovom radu utvrditi ima li u ostalim dijelovima temporala (104vd-122vd, 165ra-194vd i 237ra-240vd), koje je prema spomenutomu kriteriju izdvojio M. Žagar, vernakularnih elemenata. Takve su jezične činjenice uspoređene s rezultatima istraživanja beramskoga govora provedenog za potrebe ovoga rada s ciljem da se odgovori na pitanje jesu li temporal $\mathrm{BrBer}_{2}$ i pisali pisari kojima je materinski idiom bio beramskoga tipa ili su pišući unosili elemente beramske skupine govora. Dvije su među njima temeljne: odraz jata (B) u gramatičkim morfemima i odraz stražnjega nazala QSb (ؤ). Uvećani je broj tzv. ekavizama u prvim dvama za ovaj članak analiziranim dijelovima zasigurno posljedica tendencije da se ekavski odraz jata (B) piše slobodnije, odnosno percepcije jata (B) kao vokala e-tipa (DAMJANOVIĆ 2011: 284-285), ali moguće i utjecaja beramskoga govornoga tipa, to više što se ekavske zamjene mogu naći i u gramatičkim

${ }_{1}$ Istraživanje je za ovaj članak provedeno u okviru projekta Centra izvrsnosti za hrvatsko glagoljaštvo Staroslavenskoga instituta u Zagrebu. V. URL: https://beram.stin.hr. 
morfemima. Ikavizmi u leksičkim morfemima, uz zamjenicu če (安引), govore pak u prilog predlošku s krčkoga vrbničkoga područja. Kada je riječ o odrazu stražnjega nazala $Q S b$ ( $\left.\mathscr{C}_{\mathcal{E}}\right)$, može se pretpostaviti da je primarni refleks u beramskomu govoru bio $o$ (g) (danas dosljedan u gramatičkim morfemima, paralelan $\mathrm{s} u$ (刃) u leksičkim, u koje inovacije brže prodiru), a da je u ovom temporalu $u$ (尹) bilježen prema normi hrvatskoga crkvenoslavenskoga jezika. U tom bi se smjeru i rijetke zamjene s $o$ (g) - to više što je već i na nekoliko takvih primjera u sanktoralu BrBer $_{2}$ upozorio M. Mihaljević (2011: 131) - mogle promatrati i kao utjecaj organskoga idioma.

Ključne riječi:Drugi beramski (ljubljanski) brevijar, BrBer ${ }_{2}$, temporal, vernakular, govor Berma, hrvatski crkvenoslavenski jezik, povijesna dijalektologija

\section{UVOD}

Premda se u dijelu literature pouzdanost starih tekstova kao dijalektoloških predložaka preispitivala (primjerice LUKEŽIĆ 2005: 203), recentni radovi iz dijakronijske dijalektologije govore da su upravo oni - »najvažniji i najinformativniji korpus« analize »povijesnoga razvoja nekoga dijalekatskoga sustava ili neke njegove značajke« (ZUBČ́IĆ 2015: 98). Nakon nekoliko ranijih jezičnih analiza hrvatskoglagoljskih tekstova kojima su autori nastojali utvrditi podrijetlo prevoditelja ili pisara ili područje nastanka teksta (npr. Ivan Milčetić, Vatroslav Jagić i Vjekoslav Štefanić, prema ZUBČIĆ 2015: 99) - u analizi kodeksa Bartola Krbavca, Marija Pantelić podrobnije analizira elemente autorova govora, govora područja na kojemu su kodeksi nastali i »odnos pisane i govorene riječi« (PANTELIĆ 1964: 67), dakle potvrđuje da uz određeni oprez i književna djela mogu biti dobrim izvorom dijalektnih podataka. I u kasnijim radovima, analize provedene takvom metodologijom pokazuju da su autorske intervencije - primjerice u hrvatskim crkvenoslavenskim tekstovima ${ }^{2}$ - dovoljno uočljive da bi se mogle izdvojiti kao odmak od već utvrđene postojeće književnojezične norme toga jezika ili staroslavenskoga. ${ }^{3}$ Sanja Zubčić naglašava da su zaključci precizniji »upotpune li se te spoznaje potencijalnim spoznajama o mjestu nastanka teksta ili o mjestu za koje je tekst namijenjen, o biografiji pisara, ostalim njegovim djelima i drugim potrebnim izvanjezičnim čimbenicima« (ZUBČIĆ 2015: 101). Među tim

2 Prema mišljenju se autora gramatike Hrvatski crkvenoslavenski jezik u drugoj polovici 13. stoljeća počinje stabilizirati nova redakcijska norma hrvatskoga crkvenoslavenskoga jezika, jezika koji je imao funkciju prvoga književnoga jezika Hrvata, dok je prva revizija starih tekstova provedena već u 12. st. u smislu prilagođavanja Vulgati (MIHALJEVIĆ 2014: 15; BLAŽEVIĆ KREZIĆ 2016: 150).

3 Usp. analizu Greblova Tlmačenia od muki gospoda našego Isuhrsta (ZUBČIĆ 2010: 631647), analizu jezika grobničke brašćinske knjige 16. i 17. st. (LUKEŽIĆ 2005) itd. 
drugim izvanjezičnim čimbenicima ključni su i - tip teksta, vrijeme nastanka teksta i formiranost književnih stilizacija.

S obzirom na tip teksta koji je predmetom analize ovoga rada - brevijar, kao i na njegovu dataciju - 15. stoljeće (MIHALJEVIĆ 2011: 138), odmaci od norme hrvatskoga crkvenoslavenskoga jezika u temporalu Drugoga beramskoga (ljubljanskoga) brevijara $\left(\right.$ BrBer $\left._{2}\right)$, koji se pod sign. Ms 163 čuva u Narodnoj in univerzitetnoj knjižnici u Ljubljani, mogli bi biti rezultat prodora elemenata vernakulara (pisareva zavičajnoga govora ili pisarske škole), ${ }^{4}$ jer se hrvatski povijesni književni jezici (nastali na jednom od narječja ili hibridu) javljaju u 16. st.

Dosadašnji pokušaji utvrđivanja vernakularnih činjenica na prvih 50 od 264 lista temporala BrBer $_{2}$ - u radu Silvane Vranić iz 2018., kao i u izlaganju S. Vranić i S. Zubčić iz 2017. g. ${ }^{5}-$ s aspekta dijakronijske dijalektologije pokazuju da taj dio temporala pripada sjevernomu, krčko-istarskomu, tipu liturgijskih tekstova. ${ }^{6}$ Razlog je takvomu zaključku u prvom redu pretežitost $\check{z} d$-refleksa jotacije dentala $d$ (I̋) iako je na dijelu 38ra-50ra ipak rjeđe zastupljen, što pridonosi pretpostavci o novomu pisaru.

Različito od Josefa Vajsa koji je prema ispisanosti rukopisa pretpostavio da je prvih 39 listova $\mathrm{BrBer}_{2}$ pisao jedan pisar, a listove nakon toga ispisivao drugi (VAJS 1910: XVI), Mateo Žagar na temelju osnovnoga dojma pisma (slovnih proporcija, smještaju u retku) - dovoljno različitim vidi barem šest pisarskih rukopisa. ${ }^{7}$ Prvih 20 listova pripisuje jednomu pisaru, dijelove 21ra-30rb drugomu, a 41vc (novi arak) - 50vd trećemu. Prema udjelu su vernakularnih značajki i dijelovi 30vc-37vd bez bitnih različitosti, što govori ili o pripadnosti pisara istoj pisarskoj školi ili o zajedničkomu materinskom govoru.

Vodeći računa o (ne)pouzdanosti starih tekstova kao dijalektoloških predložaka, u ovom će se radu jednakom metodologijom - dijakronijske ili

4 Iz zapisa na marginama razvidno je da se $\operatorname{BrBer}_{2}$ koristio u Bermu (MIHALJEVIĆ 2011: 126), ali su i pojedini jezični elementi sanktorala ovog Brevijara svojstveni ekavskim središnjoistarskim govorima (MIHALJEVIĆ 2011: 138).

5 S. Vranić analizirala je prvih 20 listova za temu Neke dijalektne značajke u Drugom beramskom (ljubljanskom) brevijaru, izloženu na konferenciji Sarajevski filološki susreti 2016. (objavljeno 2018.: VRANIĆ 2018), a ostatak su istražile S. Vranić i S. Zubčić za temu Norm in the language of Istrian Glagolitic breviaries, izloženu 2017. g. na konferenciji pod nazivom 49th ASEEES Annual Convention u Chicagu.

6 Drugi je tip kodeksa nastajao na zadarskom području i u Lici i Krbavi (zadarsko-krbavska, južna skupina). Usp. TANDARIĆ 1960: 137.

7 M. Žagar iznio je tu podjelu u izlaganju Grafomorfološke osebujnosti glagoljskih liturgijskih rukopisa XIV. st. na Međunarodnom znanstvenom skupu »Fenomen glagoljice (Biograd - Zadar, 12. i 13. svibnja 2017.)«. 
povijesne dijalektologije - pokušati utvrditi: ima li u ostalim dijelovima temporala $\operatorname{BrBer}_{2}(104 \mathrm{vd}-122 \mathrm{vd}, 165 \mathrm{ra}-194 \mathrm{vd}$ i $237 \mathrm{ra}-240 \mathrm{vd})$, koje je prema spomenutomu kriteriju izdvojio M. Žagar - značajki koje se razlikuju od hrvatske crkvenoslavenske norme, a koje bi se mogle pripisati vernakularu. Takve će se jezične činjenice usporediti s rezultatima istraživanja beramskoga govora provedenog za potrebe ovoga rada s ciljem da se odgovori na pitanje: jesu li BrBer $_{2}$ - osim što su ga koristili beramski klerici - pisali pisari kojima je materinski idiom bio beramskoga tipa ili su samo unosili elemente sustava beramske skupine govora na području kojeg je nastao, odnosno pisarske škole.

Govor Berma pripada središnjoistarskomu poddijalektu ekavskoga dijalekta čakavskoga narječja (VRANIĆ 2005: 335). U taj je dijalekt uključen (BELIĆ 1912; RIBARIĆ 1940; MAŁECKI 1930; IVIĆ 1961; UJČIĆ 1985; ŠIMUNOVIĆ 1985; ŠIMUNOVIĆ 2011; PLIŠKO 2003) u prvom redu zbog dosljednoga ekavskoga odraza jata (B) u kategoriji leksičkih i gramatičkih morfema. Unutar središnjega istarskoga poddijalekta dijelom je pazinske skupine govora (VRANIĆ 2005: 335). Govore te skupine osim nekih korijenskih i tvorbenih ikavizama obilježuje i nešto morfoloških ujednačavanja u L jd. imenica m. i s. r. i u L mn. istih imenica. Za njih je tipična i interferencija zamjene stražnjega nazala $o s ъ$ (g) kao $o$ (g) i kao $u$ (刃) u korijenskim morfemima, uz dosljednost $o$ (g) u gramatičkim morfemima, dok je u glagola II. vrste $-\mathrm{u}$ infinitivu, u glag. prid. rad. i glag. prid. trp. kada se tvore od infinitivne osnove - ovjeren sufiks -ni- (-P8-) <*-ny. Upravo bi distribucija zamjena tih dvaju vokala u naznačenom korpusu omogućila precizniji odgovor na pitanje o udjelu osobitosti beramskoga tipa govora u temporalu BrBer $_{2}{ }^{8}$

U daljnjemu će se tekstu uz spomenute elemente promatrati i druge značajke, relevantne bilo na razini udjela čakavštine u tekstu, bilo na razini udjela

${ }^{8}$ U dosadašnjoj je literaturi govor Berma spominjan ili istraživan i kao dio sjeverozapadnih čakavskih govora u Istri (VERMEER 1982; KALSBEEK 1983; ZUBČIĆ 2006; ZUBČIĆ 2017) zbog pojave neocirkumfleksa u kategoriji e-prezenta (naglasni tip $a$ s osnovom na sonant) i je-prezenta (naglasni tip a) (ZUBČIĆ 2017: 106). I za ovoga je, najrecentnijega istraživanja govora Berma, ovjeren neocirkumfleks u kategoriji prezenta (npr. 3. 1. jd. prez. bûbne, kupûje). Potvrđen je peterovokalni sustav s dva diftonga: ie od dugog è bez obzira na podrijetlo (va lieven, ciedit; miesa $\mathrm{G}$ pieti; palienta, ufiendi jd. m. r. glag. prid. rad. 'uvrijediti') i uo od dugog o bez obzira na podrijetlo (muоš, ruoka; kantaduor 'pjevač', sakamuor). Specifičan je izgovor vokala $a$ u kontaktu s nazalima - [ə] (KALSBEEK 1983: 255). Iako se bilježi rjeđe no za istraživanja krajem 20. st. i neki ga govornici više ne izgovaraju, još uvijek se može promatrati kao dio govora (məvrica 'duga', məndula 'badem', zvən bənde 'sa strane', nənke 'niti', məčak). Tri su naglaska (česte su dublete ostvaraja neoakuta i dugoga silaznoga naglaska) ovjerena u svim pozicijama u riječi, sačuvana je prednaglasna, a utrnuta zanaglasna duljina (dëlavac, čerëpnja, vrtët; bûbne 3. 1. jd. prez., okuôli, svakamuôr; žiẽnskah L mn., griẽlgriê 3. 1. jd. prez., edanpũt; ciedit). 
konkretnih sustava pazinske skupine, odnosno beramskoga tipa govora - i usporediti s ovjerama u korpusu ovoga rada, kao i s rezultatima ranijih istraživanja temporala $\mathrm{BrBer}_{2}$ prema jednakim kriterijima.

\section{JEZIČNE ZNAČAJKE}

\subsection{Upitno-odnosna zamjenica za neživo}

$\mathrm{U}$ dosada istraženim dijelovima temporala $\mathrm{BrBer}_{2}$ potvrđena je hrvatska csl. upitno-odnosna zamjenica čto (9 puta) i oblici tvoreni njome: veznik počto (15ra, 43ra), neodređene zamjenice ničtože (3rb) i nêčto (30vc). Zamjenica čto i oblici njome tvoreni dominantni su i u preostalom dijelu temporala, što je, uz ostalo, uvjetovano sadržajem teksta (18 pojavnica do 50. lista, nakon toga preko 300).

$\mathrm{U}$ ranije analiziranim dijelovima temporala $\mathrm{BrBer}_{2}$ - genitiv (dalje: $\mathrm{G}$ ) česo zastupljen je samo iznimno (37vd), a u ovomu je korpusu (110vc, 115ra, $115 \mathrm{rb}, 115 \mathrm{vc}, 182 \mathrm{rb}, 185 \mathrm{ra}, 239 \mathrm{rb})$, kao i izvan korpusa, češći. Jednako je i s osnovom česo, npr. u nečesože (31vd), ničesože (32rb), koja je u korpusu ovoga rada (7 puta) i na listovima izvan korpusa učestalija.

Na ranije analiziranim listovima prilog ili veznik začb/zač', svojstven većini čakavskih govora, pa tako i beramskomu, potvrđen je 5 puta. U korpusu ovoga istraživanja nije zabilježen, ali se javlja na ostalim listovima nakon 50-oga u više navrata (54ra, 60ra, 93rb, 95ra, 133rb, 205vd, 209rb, 211rb, 215ra, 215rb, 222ra, 223ra, 226vd, 257vd /zač 264ra), a prilog načb na 211vc.

Refleks jerova $b$ (I) i $b$ ('H) u čakavskim je govorima trojak: $a$ (th) u najvećem dijelu govora, $e$ (引) i $a$ (内) pod određenim uvjetima u omišaljskom govoru i vrbničkom tipu na otoku Krku te u nekim creskim i sjevernološinjskim govorima (u potonjim uz $o$ u brojevima) (VRANIĆ 2005: 173), a $o$ (g) i $a$ (th) u dobrinjskom govoru (LUKEŽIĆ; TURK 1998). ${ }^{9}$ Stoga se uporaba lika če (安引) ${ }^{10}$ pripisuje spomenicima koji su ili nastali na krčkom vrbničko-omišaljskom području ili su podrijetlom s toga područja (MIHALJEVIĆ 2014: 144), pa M. Mihaljević, zbog primjera koje je uočio u sanktoralu $\mathrm{BrBer}_{2}$, pretpostavlja da je korišten predložak s toga areala (MIHALJEVIĆ 2011: 133). Zamjenica je če u temporalu iznimkom do 20. lista (11vd), češća od 20. do 50. lista (28ra, 30vc, 41ra, 41rb), a od 50. lista do kraja temporala javlja se samo u primjeru: če ponê bilo bi (58rb) (uz ča 104ra, 247ra). Dakle, u korpusu predviđenom za

\footnotetext{
${ }^{9}$ Uz nešto primjera s neizmijenjenim šva pod određenim uvjetima među čakavskim ekavskim govorima u rubnom govoru Brdca (VRANIĆ 2005: 175).

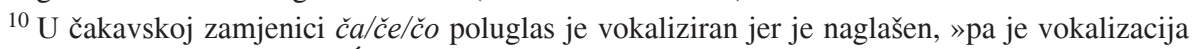
redovita pojava« (MALIĆ 1991: 91).
} 
ovaj rad nema potvrde toga čakavskoga lika, što može svjedočiti o nastojanju pisarâ da očuvaju normu hrvatskoga crkvenoslavenskoga jezika izbjegavanjem te markantne činjenice, a veći broj zabilježenih likova začb/zač izvan korpusa - da su pri prijepisu oblika tvorenih upitno-odnosnom zamjenicom bili manje oprezni i propuštali elemente vernakulara.

\subsection{Prijedlog v (ШШ) i prefiks $v$ - (ШШ-)}

U hrvatskim crkvenoslavenskim tekstovima prijedlog (i prefiks) $v(-$ ) (ㅍ/-/) različito je bilježen: osim što može stajati samostalno, uza nj je štapić (I), apostrof ( $\left(^{*}\right)$, stražnji poluglas (pa i reflektiran kao $o$ /g/), a može biti zamijenjen i vokalom $u$ (刃) (VINCE 2014: 271). Zabilježena je i zamjena poluglasa vokalom $a$ (th), koja se u hrvatskoj dijalektologiji drži hijerarhijski vrhunskom čakavskom značajkom jer slijedi tendenciju pune čakavske nepreventivne vokalizacije poluglasa u slabom položaju (MOGUŠ 1977: 21).

U govoru je Berma za ovoga istraživanja uz prijedlog va i jednak prefiks, koji se može i elidirati, ovjeravano i u(-): va boške, va glave, va/u škatule; vajka, Vazan/Vozən ${ }^{11}$; u lieven žepu, u Žminj, u našeh kućah, u kasun; umriet, ubos, udovica, unuka; ziet.

U spominjanim, dosad pretraživanim dijelovima temporala ovoga brevijara pretežit je $v(-)$, dok je $u(-)$ zabilježen u glagolu uprašaet' 3. 1. jd. prez. (12ra) / vprašati (21vc), a često je upravo va u određenim pozicijama.

I u ovom je korpusu distribucija jednaka. Dominantno je $v(-): v$ premilostivo, vd(a)nb, vtrpeni, v(o)no, v pustinu, v pustinu, vs(ve)ti, vdomb, vskreseniê (104vc), vsiêetb, vskoree (104vd), vis'tinu (104vd, 110rb, 112ra itd.), vživote, $v$ dusê (105ra), v kreposti (106vc), v trpeni, $v$ domb (106vd) itd., ali i $v$ erusolomb (106vd, 108ra, 112rb, 112vd), v eûpatb (117vd), v eûptê $(122 \mathrm{vc}), v$ er(u)s(o)l(i)mi (166ra), v edin' (178vc), v edinomb (193vc) itd.

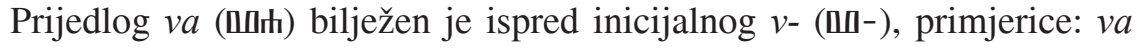
vsehb (104c), va v'sêhb, va večnie (105ra), va vrime (165vd), va v'sako (167ra), va vasb (167vd), va verê (190ra); pred stražnjim vokalom: va onêhb (106ra), va obrazb (106vd, 109rb), va oganb (106rb), va utrobi (105ra), va odiû (167vc), va onomb $(190 \mathrm{vc})$, va ogni $(237 \mathrm{rb})$, kao i pred slijedom od dvaju konsonanata: va 'ne (105ra), va t'me (105vc), va d(a)ni (240ra) itd. Potvrđen je i ispred riječi koja počinje prednjim vokalom: va iskrnemb (106ra), va ispravlenii (113ra), va is 'povedi (113rb), va imnahb (165ra), va ime (119rb, 167ra, 167vd, 168ra, 169rb, 185ra, 185rb, 186ra), va istoč niki (177vc), va is'celenie (181rb), va

\footnotetext{
${ }^{11}$ Iako je u sufiksu jaka vokalnost, leksem ulazi u čakavske primjere vokalnosti zahvaljujući svojemu prefiksu (MALIĆ 1991: 90).
} 
inihb (191rb) (i ispred $i$ - koje se čita kao $j$ : va iûdei 190ra), ${ }^{12}$ ponekad i pred srednjim vokalom: va ade (106rb), va asii (190ra). Prefiks va- (ППт-) zastupljen je također pred slijedom od dvaju konsonanata, pred konsonantom i pred v: vaz'mutb (105ra), vač'netb (121 vd, 190vc, 191rb), vačnetb $(237 \mathrm{vc})$, vačnemb (104ra, 117ra,121vd, 122vc, 122vd), vaz'mi (108vd) itd.; vap'etb (166vd), vavedi $(2 \mathrm{x})(104 \mathrm{vc}) .^{13}$

Međutim, u hrvatskim se crkvenoslavenskim tekstovima oblik s vokalizacijom poluglasa u $a$ čakavskim elementom može odrediti tek u poziciji pred početnim prednjim vokalom, u ovom korpusu ispred $i$ (в). Naime, $v a$ (ППњ) je u tim tekstovima uvjetovan glasom koji slijedi: najčešće je ispred inicijalnoga v- (ШШ-) sljedeće riječi, ispred početnoga vokala stražnjega niza, kao i pred slijedom od dvaju konsonanata (ZUBČIĆ 2010: 635).

Noviji prijedlog $u(\boxplus))^{14} \mathrm{u}$ istoj funkciji kao $v$ (ШШ) rjeđe je zastupljen, ali je ipak učestaliji izvan korpusa, npr. u g(ospo)d(i)nu b(og)u (63rb), u reki (68rb), u ml'ku (151rb), u c(êsa)rstvê (216vc), i u korpusu iznimno, npr. u mesti (113rb) - kao i prefiksalno u-: uprašal (108vc), upraša (110ra), uprašanie $(119 \mathrm{vc})$, uprašati $(180 \mathrm{vd})$, uprašaše (225ra), uprašano (221rb), ugaždati (108vd), ugod'na (105ra), ugodise (107rb), ugodno (237ra), uzrit' (105rb), uzriše (115ra), uzrite (166vd), uzriši (239vc).

Čakavska je značajka pune nepreventivne vokalizacije u korpusu zabilježena i u prilogu kadê (106vc, 115vc, 176rb, 243ra) / kade (240vc), kao i u ranije istraživanom korpusu i izvan ovoga korpusa (npr. 14rb, 21vd, 28vd, 83rc, 92vd, 95ra, 156vc, 221vc, 233ra). Uz va(-) ispred riječi koja počinje prednjim vokalom - potvrdom je čakavskoga utjecaja. ${ }^{15}$

${ }^{12}$ Samo iznimno javlja se i $v(-)$ (ПШ-) ispred $i(8)$ : v ime (184vc, 185ra, 185vc), uz vis tinu (104vd, 110rb, 112ra itd.).

${ }^{13}$ Jednako je i izvan korpusa, npr.: va v'sêhb (103vc, 207vc, 234rb, 257rb); va ustn(a)hb (51vd), va ust'hb (61rb), va ustehb (65rb, 76vd), va ustêhb (75rb), va usta (77.vc), va učeni (84rb), va upv(a)ni (88vd), va oganb (147vd); v istinê (242ra), vis'tinu (preko 30 puta od 50cd do $104 \mathrm{vd})$, v eže (123vc), ali i va emu (93vd), vazamb (199ra), vazam (242vc), vazam'še (259vd) itd.

${ }^{14}$ Prijedlog $u$ u cijelomu brevijaru dosljedno stoji uz G, kao što je uobičajeno u hrvatskomu crkvenoslavenskomu jeziku (VINCE 2014: 280), npr. u formulaciji $u$ boga.

${ }^{15} \mathrm{U}$ literaturi se čakavskom pojavom drže i primjeri vokalizacije na granici osnove i sufiksa -stvo (-จாயாп9) i sl. poput cesarastvo (MALIĆ 1991: 98). Tako je i u temporalu BrBer ${ }_{2}$ u ovom korpusu npr. cesarastvi (169vd), bogatastvo (173rb), kao i izvan, npr. bogatastviê $(97 \mathrm{rb}, 130 \mathrm{vd}, 197 \mathrm{rb}, 255 \mathrm{vd})$. No, za suvremene čakavske govore takvi primjeri nisu specifični, već su im svojstveni oni s provedenim slabljenjem napetosti nakon redukcije poluglasa, npr. bogastvo. 


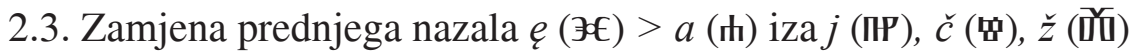

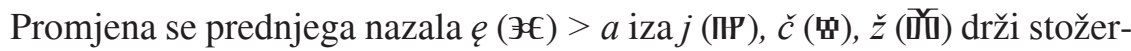
nom značajkom čakavskoga narječja. Ranije je bila zastupljena u većem broju primjera, danas je uglavnom u manje frekventnim riječima (MOGUŠ 1977: 35-36), a rijetko se ovjerava i u drugim hrvatskim narječjima. Pretpostavlja se da je proces završen krajem 10. st. i da je nakon toga zamjena ujednačena na $e$ (a) bez obzira na glas koji prethodi nazalu.

Potvrđena je i u beramskom govoru u osnovi glagola izvedenih od $*_{i m}$ s protetskim $j$ - (IIP-), npr. zajat, te u imenica jačmik i jazik (PLIŠKO 2003: 285; VRANIĆ 2005: 177-181), za ovoga istraživanja i zajik, ali želi (su na ruoke), počet itd.

Ta je promjena u hrvatskim crkvenoslavenskim tekstovima ujednačenija »nego u suvremenim čakavskim govorima i starim tekstovima pisanim čakavskim narječjem« (MIHALJEVIĆ 2014: 78). Dosljednije je bilježena u nekoliko osnova: češće iza protetskog $j$ - (IIP-) u osnovi glagola izvedenih od *im(npr. jati, najati), u riječi językъ (ězikb obično u značenju 'narod', a ezikb u značenju 'jezik'), a rjeđe u osnovama žęd- (npr. žâja, žaina), čęt- (npr. počali, načala) $i$ čęst- (pričasnikъ, časta $\mathrm{N}$ jd. ž. r.) (MIHALJEVIĆ 2014: 78-79). U dijelu se spomenika iznimno nađu i drugi primjeri poput klę $>$ kla.

Na prvih 50 listova temporala, kao i u za ovaj rad analiziranom korpusu, stariji je refleks $a$ (th) zastupljen iza $j$ (IIP) najčešće u językъ i prijęti. Osnova êzik- u 137 je pojavnica, npr. êzik' (107vd), êzikb (109vd, 177vd, 194vc itd.), a 153 oblika s istim su korijenom, npr. êzici (106vc, 110ra, 194vd), êziki (193vd 4x, 194ra, 194vc, 194vd), êzikomb (107ra, 177vd, 193vc), uz ezik- (22 pojavnice u tekstu). U oblicima izvedenim od *im- koji imaju protetsko $j$-zabilježen je i čakavski rezultat: priêtb (107vd, 118vd, 120rb, 167vd, 172ra, 240vd), priêti (112ra, 123rb, 165vc, 168vc), priêt'na (105ra, 237rb), priêt'no (105rb, 105vc), êti (122vc, 240vd), poêtb (108rb, 108vc, 110rb, 111rb). Korijen čęt-ima čakavski lik čat- u ovom korpusu, npr. počaše (168vc, 192rb, 193vd, 194ra x3). ${ }^{16}$

Ovakva distribucija promjene prednjega nazala $e$ (Э夭) u $a$ (th) nije dakle samo posebnost analiziranoga temporala, ali je najvećma podudarna i s primjerima zabilježenim u govoru Berma, a kao i ranije analizirani dijelovi pridružuje ovaj brevijar sjevernomu tipu kodeksa i potvrđuje da hrvatski crkvenoslavenski

\footnotetext{
${ }^{16}$ Jednako je i izvan korpusa pretraživanoga za ovaj rad: poêtb (98rb), priêt'na (128vd, 135ra), ali i prieti (133vd), kao i u korijenu čęt-: počanši (7rb), počan 'ši (93vd, 263vc), poča(še) (195ra), počaše (97vd, 196vd), počal 'niku (222rb), ot počala (245vd), načan'ši (90rb); u korijenu čęst: často ‘često’ (223vc), iako je pretežito često (104ra, 161vc, 215ra), kao i u korpusu (113ra, 183ra). Promjena klę > kla zabilježena je u primjeru poklan 'knuv'izvan korpusa (101ra).
} 
»ima više glasovnih promjena koje su zajedničke sa starohrvatskim jezikom, najvećim dijelom s čakavskim narječjem « (MIHALJEVIĆ 2014: 78). ${ }^{17}$

\subsection{Promjena *dj $(* \Pi \mathrm{t} \Pi \mathrm{T})>j(\Pi \mathrm{\Pi P})$}

Čakavska jotacija prsl. skupine $* d j(* \Pi \mathrm{l} \Pi \mathrm{P})>j(\mathrm{IIP})$ (i njome tvorenih skupina) primarna je i u beramskom govoru i prema podatcima prikupljenim za ovoga istraživanja (žeja; mlaji, tuji, rojen; dažjilo) iako danas govornici ovjeravaju i neautohtoni glas $d$ ', zvučni parnjak čakavskoga $t^{\prime}$ (obrad'eno uz obrajeno, and'el).

U hrvatskim crkvenoslavenskim kodeksima češća je u južnoj skupini, a u

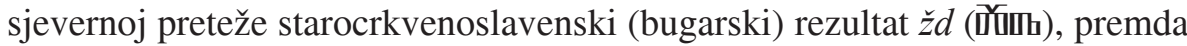
su oba potvrđena u obje skupine (MIHALJEVIĆ 2011: 129; MIHALJEVIĆ 2014: 84-85).

$\mathrm{Na}$ dosad je analiziranim listovima temporala na mjestu latinskoga i grčkoga $g$ ispred prednjeg samoglasnika uvijek bilježen đerv (IHP), a tako je i u ovom korpusu: anj(e)l(o)mb (105ra), an'jeli (105vd), an'̧ر'lski (105vd,

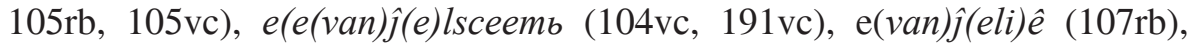
$e($ van $) \hat{\jmath}(e) l i s t b(107 \mathrm{vd})$, ar'han' ${ }^{\prime} l b(186 \mathrm{vc}) .{ }^{18}$

U cijelom je temporalu, gotovo u jednakoj mjeri kao i refleks $j$ (IIP), zastupljen refleks žd (并iाb) zahvaljujući kojemu se Brevijar može pridružiti sjevernoj skupini kodeksa: tuždi (107rb), tuždei (183ra), ugaždati (108vd), prêž'de (109vd), prežde (110rb, 180vc, $180 \mathrm{vd}, 186 \mathrm{vd}, 208 \mathrm{vc}, 234 \mathrm{vd})$, pobêždaetb (165ra), pobeždaei (167rb), roždastvoms (166vc), poroždeni (184rb), rožden' (189rb), ${ }^{19}$ osuž-

\footnotetext{
${ }^{17}$ U korijenu êzik- (B妱与-), kao i u još nekim primjerima, zastupljeno je čakavsko neprovođenje druge palatalizacije velara, npr. êziki (33 puta) uz êzici (33 puta u cijelom tekstu). Međutim, provođenje palatalizacija nestabilno je i u hrvatskom crkvenoslavenskom jeziku (MIHALJEVIĆ 2014: 82-83). U ovom temporalu nestabilnost mijene potvrđuju usporedni zapisi sa i bez velara u više oblika, npr. grêhi (15rb), grê̌sniki (15rb, 215rb), učeniki (119rb), pričestn(i)ki (220ra), ali i učenici (119rb), grêšnici (214vd), pričesnici (178rb), č(lovê)ki (44 puta), ali č(lovê) ci (34 puta), no samo dusi (177vd).

18 Tako je i izvan korpusa: $e$ (van) $\hat{\jmath}($ eli)ê (94vc, 97ra) itd.

${ }^{19} \mathrm{~S}$ osnovom rožd- (Ба⿺𠃊丆贝ाা-) 26 je pojavnica: tri su unutar ovoga korpusa, a najveći je broj primjera (15) zabilježen od početka temporala do stranice $104 \mathrm{vd}$. No, na desetak je mjesta

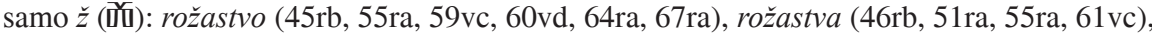
rožastviû (62ra) (uz roždastvo (54vd) i roždastva (48vd)), a na jednak rezultat u sanktoralu upozorava M. Mihaljević (MIHALJEVIĆ 2011: 129). Takav je odraz, uz druge, danas među čakavskim dijalektima svojstven jugozapadnomu istarskomu dijalektu. Prema pisanju u čakavološkoj literaturi rezultat je čakavskoga izgovora /亏̌/, pri čemu se pretpostavlja prethodan prijelaz / $/ 3 /$ u /亏̌/ (LISAC 2009: 54), što se ne očekuje za čakavske govore ekavskoga središnjoistarskoga poddijalekta jer bi parnjak čakavskomu /t'/, fonemu konsonantskoga inventara
} 
daše (166vd), ${ }^{20}$ prigvoždeni (167ra), posaždu (169ra), viždb (173rb, 173vc, $181 \mathrm{vc})$, ishoždahu (238vc), ziždûtb (240rb), mimohoždaše (240vd). ${ }^{21}$

Čakavski je refleks $j$ (IIP) prema zaključku u spomenutom izlaganju S. Vranić i S. Zubčić iz 2017. češći od 38. do 50. lista, što govori u prilog pretpostavci o drugom pisaru. Učestaliji je i u ovom korpusu, u kojem je bilježenje također različito. Predstavljen je grafemom j (đerv - IIP): rôj'niê (109vd), roĵni (110ra, 110rb), neroĵnimi (110ra), roĵstva (111ra) (s roĵ- 60 pojavnica, 8 unutar korpusa), osuĵnie (111vd), osuj(e)nie (167vd), osuj(e)nihb (191rb, 4 ukupno); s i: roišimb, roiše (110ra), roistva (111ra), roistvo (166vd); s ê (ja):

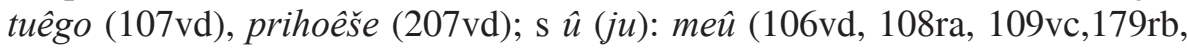
$180 \mathrm{vc}, 237 \mathrm{vc}, 238 \mathrm{vc}, 238 \mathrm{vd}, 239 \mathrm{vc})$, nareûût' (237vd). U korpusu su rijetki

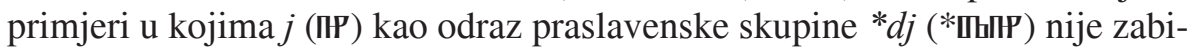
lježen nikakvim grafemom: osueni (107ra, češće izvan korpusa), a iznimno je zadržan grafem $d(\mathbb{\Pi b})$ ispred jata $(\boldsymbol{B})$ : vidêniê $(240 \mathrm{dv}) .^{22}$

Pomlađivanje teksta refleksom $j$ (IIP), zamijećeno od 38. do 50. lista, razvidno je i u ovom korpusu bez obzira na brojnost primjera s odrazom $\check{z} d$ (而而), čime se osim povezanosti s crkvenoslavenskom tradicijom, potvrđuje i bliskost s čakavskim područjem.

\subsection{Odraz jata (B)}

U tradicionalnoj je podjeli čakavskoga narječja na šest dijalekata u prvom

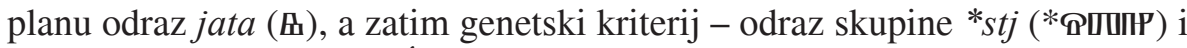
${ }^{*} s k j\left({ }^{*} \mathbf{Q}\right.$ «IIP) (BROZOVIĆ 1988: 80-90). Za ekavski je čakavski dijalekt, kojemu, kao što je istaknuto, pripada i govor Berma, presudan dosljedan ekavski odraz jata (B) u leksičkim i u gramatičkim morfemima, uz pojedinačna odstupanja ponajprije u korijenskim morfemima jer je »gramatički morfem nosilac

tih govora, bio /d'/, pa je, s obzirom na listove na kojima je prijelaz bilježen, moguće potvrditi pretpostavku o drugom pisaru tih dijelova.

${ }^{20}$ Uočeno je 12 pojavnica s istim korijenom.

${ }^{21}$ Jednako je i izvan korpusa: rožd- (125vc, 162vc, 164vd, 198ra, 261ra); utvrždeni (244vc), utvrždeniê (248vc), pos 'tiždenie (249rb), raspruždena (250vc), sliždahu (253ra), ishoždahu (254ra), moždeni (254vd), dosaždeši (255vc), poždahomb (256a), postižden (256vc), vinograždane (258vc), pohoždu (261ra), saziždite (261rb) itd.

${ }^{22}$ Različiti su načini zapisa i izvan korpusa, npr. roĵ(e)nb (54vd, 58rb), roj(e)na (59rb), osujâu (75c), osuja ahu (215rb); roistvo (263vc, 264ra), roistva (263vc); prihoêše (251rb); mê̂u (245vc, $247 \mathrm{rb}$ itd.); osuena (62ra, 132rb), osuevahu (135vc), osueni (148vd), osuenie (257ra). U primjerima milosr'diê (107ra), milosrdiemb (184vc) (i milosrdie izvan korpusa na 206vd), s izvornim nominativnim dočetkom -dzje, očekivano je $d$ (ाъ) jer takvi primjeri podliježu drugoj jotaciji koja se provodila kasnije, u 16. i 17. st. (MATASOVIĆ 2008: 162). 
sustava na morfološkoj razini« (MOGUŠ 1969: 272). Stoga bi upravo ekavski odrazi jata (B) u gramatičkim morfemima potvrdili podrijetlo pisara s toga područja ili pisarske škole u kojoj je temporal nastao.

Načelna dosljednost refleksa jata (B) u korijenskim, tvorbenim i gramatičkim morfemima (dugi se jat uvijek ovjerava diftonški) s nešto ikavskih reflekasa u beramskom govoru, kao i u najvećem broju govora pazinske skupine koje je dijelom - potvrđena je i za ovoga istraživanja, npr. ciedit, cieno 'jeftino', čerepnja, čerešnja, delavac, medved, mlieko, žliebac; imie jd. m. r. glag. prid. rad., jie jd. m. r. glag. prid. rad., vane, pole, kade, vrtet, stareja; D jd. sestre, pretelice, L jd. va škatule, va glave, na ruoke, ali gnjizdo, dica; $u d e b e l i t$, a $\mathrm{L}$ jd. imenica $\mathrm{m}$. i s. roda danas već uz rijetki nastavak -e ima i -u prema $u$-deklinaciji: na tovaru, na Pazinu, po selu, dok je L mn. istih imenica $-i$, ujednačen prema I mn., ali nastao i kao rezultat težnje k ujednačavanju s G mn. koji je »preuzeo morfem G mn. starih $i$-osnova« (VRANIĆ 2005: 311): va našeh seli, na tovari. U današnjoj pridjevskoj deklinaciji u GDLI mn. svih triju rodova (i u A mn. m. r.) prvi je dio nastavka $e$ prema tvrdoj zamjeničkoj sklonidbi od jata: va nekeh $\mathrm{L}$ mn., ali i u pridjeva: $z$ veleh, puli stareh $\mathrm{G}$ mn.

$\mathrm{U}$ dijelu se literature o hrvatskom crkvenoslavenskom jeziku jat (B) tumači kao zaseban fonem, ${ }^{23}$ a vokal $e$ (3) ili $i$ (8) na mjestu jata (B) smatraju unosom iz govornoga jezika (MIHALJEVIĆ 2009: 299), dok dio autora, zbog takvih zamjena već u 12. st., više ne govori o jatu (B) kao elementu fonološkoga sustava toga jezika (MIHALJEVIĆ 2009: 299). Jat (B) je u hrvatskim srednjovjekovnim tekstovima i dalje bilježen, ali su zastupljeni i ikavskoekavski, ekavski (s nešto ikavizama) ili ikavski refleksi. Čest neizmijenjeni grafem za jat (B) S. Damjanović pripisuje percepciji jata (B) kao glasa $e$-tipa (DAMJANOVIĆ 2011: 284-285) - što potvrđuju i obrnute zamjene: vokala $e$ (etimološkoga, ali i onoga podrijetlom od prednjega nazala, ZUBČIĆ 2010: 640) grafemom jata (B). U gramatičkim su morfemima u imenica hrvatskih srednjovjekovnih tekstova dominantni ikavizmi, rjeđi u tvorbenim morfemima (DAMJANOVIĆ 2011: 285). U pridjevskoj su deklinaciji prevladali gramatički morfemi određene sklonidbe (POŽAR 2014: 166-167), a zabilježeni su i oblici tvrde zamjeničke promjene (POŽAR 2014: 169-171).

$\mathrm{Na}$ prvih 20 listova temporala $\mathrm{BrBer}_{2}$ grafem jata (B) dominira u svim pozicijama, s nešto zamjena vokalom $e$ (uglavnom u tvorbenim morfemima), $\mathrm{s} i$ u primjeru prelipi, i oblicima duge pridjevske deklinacije s formantom -i-. Iako od 20. do 50. lista u leksičkim morfemima i dalje prevladava grafem jat (B), češći je no u ranijima grafem $e$ (3), a paralelno je s $e$ (3) i s grafemom jata

\footnotetext{
${ }^{23}$ U brojnim buzetskim govorima čakavskoga narječja jat (B) je zadržao svoju posebnost iako je često ovisan o naglašenosti/nenaglašenosti, duljini, pa i poziciji.
} 
(B) u nekoliko gramatičkih morfema imenica zapisan $i$ (B). U pridjevskoj je deklinaciji također $-i(-8)$.

U sljedeća dva za ovaj članak analizirana dijela: 105ra-122vd i 165ra$194 \mathrm{vd}$ zastupljeniji je $e$ (引) u leksičkim morfemima: ${ }^{24}$ hlebb, strelb, verovalb (104vc), zapovede, pos'peši, ispove(daite), smereni, veri, krepki, v'svetb, blagodet'na, pobedimb, va večnie, zapovede (105ra), osenit' (105rb), v kreposti, zvezdb (105vc), videvb, videvbše (166b), verova (167ra), razumevâ̂cu $(184 \mathrm{vc})$, več'nuй $(184 \mathrm{vd})$, videv'šimb $(187 \mathrm{vd})$, razumevati $(192 \mathrm{rb})$, svetblo, svetlei (166vd), svetil'nik' (170rb, 171rb, 172vd), svetil'nikb/svetilbnik' (170rb), svetil'nika (175rb, 181vc), svetbliti (187ra), svet'lo, otveĉavaetb $(189 \mathrm{vc})$ itd. ${ }^{25}$ Rijetko je $e$ i u gramatičkim morfemima, usporedno s onima s grafemom jata: sêbe $\mathrm{D}(104 \mathrm{vc})$, vživote, va m'ne (105ra), vtele (107vd, 121ra, $166 \mathrm{vd})$ / o têlê (186vc), o tebe (105ra), putehb, v mestehb (122vd), v narodehb (165rb), vsehb (166ra), v svete / svetê (184vd), što bi moglo biti relevantno za potvrdu podrijetla pisara tih dvaju dijelova s područja Berma ili nastanka na tom području. No, i ikavska je zamjena češća nego na prvih 50 listova:26 propovidati (175rb, 194rb), vrime (105rb, 105vc, 107ra, 107rb, 111 vd, 114ra, $118 \mathrm{rb}, 118 \mathrm{vc})$, vrimena $(104 \mathrm{vc}, 110 \mathrm{vc})$, vrimenihb (106vd), vrimenb (112rb), vrimeni $(113 \mathrm{vd}),{ }^{27}$ crikvenêmb $(105 \mathrm{rb})$, do nedile cvit'ne, sidecee $(105 \mathrm{vc})$, grihom (115ra), ričs (115rb), zvire, živilb (116ra), slipi (116vd), gdi (167vd) itd., i uglavnom slijedi Jakubinskij-Meyerovo pravilo, koje funkcionira u ikavsko-ekavskim čakavskim govorima, pa i u krčkom vrbničkom govornom tipu. Međutim $i$ na mjestu jata (B) u gramatičkom morfemu poput va utrobi (105ra), u tvorbenom gdi (167vd i dvije potvrde izvan korpusa - na 261vd i 163rb listu) samo je iznimkom dok je prema istomu pravilu očekivana upravo ta zamjena (LUKEŽIĆ 1990: 13).

Uvećani je broj tzv. ekavizama zasigurno posljedica tendencije da se ekavski odraz jata piše slobodnije, odnosno percepcije jata (B) kao vokala $e$-tipa

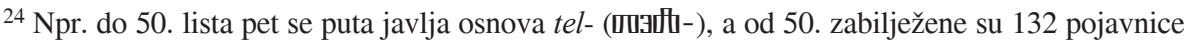
(samo jednom tilo na 204vc): od 105ra-122vd ekscerpirane su 22 pojavnice, a niti jedna s jatom; od 165ra-194vd takvih je pojavnica 40 i jedna s jatom; a od 237ra-240vd nema nijedne pojavnice s $e$ (3), dok je s jatom (B) samo jedna. Ovaj je primjer zanimljiv i zato što se s ekavskim odrazom ovjerava i u mnogim ikavsko-ekavskim govorima prema Jakubinskij-Meyerovu pravilu (LUKEŽIĆ 1990: 13).

${ }^{25}$ I izvan korpusa: svetblit (203vd), svetb 'savjet' (211vc), svetb 'svijet' (236rb, 246ra, 247ra), svetilnike (252ra), svetilb (252vc), svet' leci $(254 \mathrm{vc})$, ob'sedetb (246ra), sedê (246rb), itd.

${ }^{26}$ Jednako je i izvan korpusa: propovidati (94d), vrime (66d, 94vd, 95vd, 97vc, 99vd, 100vd, $101 \mathrm{vd}, 103 \mathrm{ra}, 123 \mathrm{vc}, 261 \mathrm{ra}, 261 \mathrm{rb}, 263 \mathrm{rb})$, vrimena $(76 \mathrm{vd}, 91 \mathrm{vc}, 98 \mathrm{vd}, 99 \mathrm{ra})$, vriment (103rb), vrimen', vrimenbno (103vd), vrimene (124c), vidilb (160ra) itd.

${ }^{27}$ Od 50. lista zabilježene su 102 pojavnice s likom vrim- (ПББв̈-), a s e (Э) u korijenskome morfemu samo 16. 
(DAMJANOVIĆ 2011: 284-285), ${ }^{28}$ ali moguce i utjecaja beramskoga govora, to više što su češće ekavske zamjene u gramatičkim morfemima. Ikavizmi pak upućuju na predložak s krčkoga vrbničkoga područja.

U trećem dijelu, 237ra-240vd, opet prevladava grafem jata (B) uz rijetku ikavsku i ekavsku zamjenu: vêra, nevêran, posrêde, trpêti, bolêzni, trpêi, pospêši (237ra), grêhi (237rb), srêdu (237vd), poslêduûcûu (237vd), mêstê (237vd), prêminuet' (237vd), slêdeĉee (237vd), sagrêšetb (238vc), ubêžah' (239ra), črêva (239rb) itd., pa i u gramatičkim morfemima: $v$ strasê L jd. (237ra), mêstê L jd. (237vd), po domêhb (238vc), ali: miseca (237vd), mis(e)ca (238rb, 238vd), slideĉû, pon(e)dil'ka / pon(e)dilka (237vd), prid' (239rb), sidiše (239vd); poslednem', pred, prestupiše (237ra), razdelaût' (238vd), kade $(240 \mathrm{vc})$, vetra $(240 \mathrm{vd})$, urežut (240vd). Ovakva distribucija jata (B) i njegovih zamjena ide u prilog zaključku o drugom pisaru u odnosu na prethodna dva dijela.

\subsection{Odraz stražnjega nazala $Q S b$ (g્屯)}

Kao što je spomenuto, dvojnost zamjene stražnjega nazala $o s ъ$ (got) kao $o$ (马) i kao $u$ (尹) u korijenskim morfemima te kao $o$ (g) u gramatičkim morfemima korpusa, bila bi relevantna značajka za određenje utjecaja beramskoga govora na temporal BrBer $_{2}$. Naime, u govoru su za ovoga istraživanja potvrđeni $o$ (घ) i $u$ (刃) u korijenskim morfemima: gobica 'gljivica', klopak 'klupko', muоš 'muž', na ruoke, ruop; kus 'komad', gusienica, a u gramatičkim je morfemima dosljedna zamjena vokalom o (马): ubolijo 3. 1. mn. prez., pejo 3.1. mn. prez., čujo 3. 1. mn. prez., za južino, večero, marendo A jd. itd. Sufiks je u glagola II. vrste -ni- (-P8-) < *-ny: nagnit, stisnit, kleknit. I u ostalim je suvremenim istarskim čakavskim ekavskim govorima dvojnost / trojnost odraza stražnjega nazala uobičajena (VRANIĆ 2005: 186-191). U gramatičkim morfemima koji nose sustav u svim je pazinskim (ali i u susjednim žminjskim govorima i u većini labinskih govora, koji su smješteni jugoistočno od pazinskih) dosljedna zamjena vokalom $o$ (घ) (osim u rubnom govoru Tinjana), a

${ }^{28}$ Usto, razvidno je iz primjera da je u istoj riječi moguć $e$ (马) i $i$ (8), ali i hiperkorektni grafem $\hat{e}$ (B) za primarni $e$ (ヨ) (DAMJANOVIĆ 2011: 285) ili $e$ (引) od prednjega nazala $e$ (अ巨) (ZUBČIĆ 2010: 640), što potvrđuje tu pretpostavku, npr. sêbe $\mathrm{D}$ (104vc), sebê $\mathrm{G}, \mathrm{A}(107 \mathrm{rb}, 116 \mathrm{vd}$, $117 \mathrm{ra})$, sêbê (105vd), na sêlê (115ra), t(e)bê (121vd, 239ra), $k$ vêcer(n)i (167rb), vavêdeši (237ra), a zabilježeni su i pseudoikavizmi: $k$ vičer'namb (105ra), $k$ vičerni $(121 \mathrm{vd}, 128 \mathrm{vd}$, $167 \mathrm{vc}, 168 \mathrm{ra}, 169 \mathrm{ra}, 169 \mathrm{vc}, 171 \mathrm{rb}, 182 \mathrm{ra})$, privičeriti (165ra), na vičeru (179rb), navičerje (186vc), navičer'e (191vc, 192ra) (usporedno s večer-) itd., čest i u čakavskim organskim idiomima. 
pretežita je i u većini korijenskih morfema (ruoka, puot, zuop). Sufiksom se u glagola II. vrste odvajaju žminjski i središnji pazinski govori (Pazina, Lindara

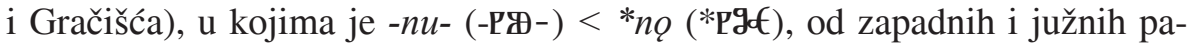
zinskih (Beram, Bazgalji, Bertoši i Heki, s učestalijom zamjenom stražnjega nazala vokalom $o$ (g) u korijenskim morfemima, te izdvojenim govorom Tinjana), u kojima je -ni- (-P8-) < *-ny- (VRANIĆ 2005: 188-189). Boljunskim je govorima (kao i većini rubnih pazinskih govora - VRANIĆ 2005: 189), smještenima sjevernije, odnosno jugoistočno od buzetskih, također svojstvena dosljednost zamjene vokalom $o$ (g) u gramatičkim morfemima, dvojnost $o$ (马) i $u$ (刃) u korijenskim morfemima, a zamjena vokalom $a$ ('t) u sufiksu *no (*pgt) glagola II. vrste.

U svim je analiziranim dijelovima temporala, kao i u hrvatskom crkvenoslavenskom jeziku (MIHALJEVIĆ 2014: 78), stražnji nazal osb (ğ zamijenjen vokalom $u$ (丹) (odrazom već od 12. st. - MATASOVIĆ 2008: 171) u svim pozicijama, pa tako i u korpusu za ovaj članak: mužb, putb $(104 \mathrm{vc})$, sutb

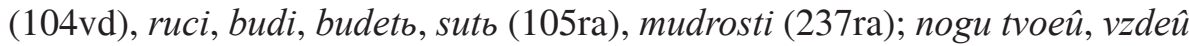

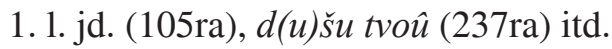

$\mathrm{U}$ ranije analiziranom korpusu zabilježen je primjer s $o$ (g) u korijenskome morfemu pojavnice premodrostiû (32vc), ali i premud'rostb (32vc), a u ostatku temporala nekoliko je ovjera sa zamjenom o (g): u korijenu modr 'stvuite(139ra), u gramatičkom morfemu u korpusu ne možaho (133rb) i vistino (100ra), dakle izvan promatranoga korpusa, ali nakon 50. lista. ${ }^{29} \mathrm{~S}$ obzirom na mali broj primjera teško je zaključiti jesu li oni samo pogreška pisara, odnosno grafijska zamjena $u$ (刃) sa $o$ (马), ili iznimkama pod utjecajem govornoga jezika.

U radu o jezičnim značajkama Greblova Tlmačenja od muki gospoda našega Isuhrsta S. Zubčić upozorava - na temelju današnje distribucije zamjene stražnjega nazala vokalom $o$ (g) i $a$ (th) u buzetskim govorima te zamjene stražnjega nazala vokalom $o$ (g) u tekstu (iako u relativno malom broju primjera), kao i zapažanja o tom odrazu u glagoljskom notarskom protokolu iz Draguća - da »refleks $u$ u analiziranome tekstu nije autohton, odnosno da nije refleks koji je nekoć prevladavao u buzetskom kraju« (ZUBČIĆ 2010: 638).

${ }^{29}$ Pojavnica sobota zabilježena je i u staroslavenskom (DAMJANOVIĆ i dr. 2004: 248.; DAMJANOVIĆ i dr. 2004: 265) i u hrvatskom crkvenoslavenskom jeziku, ali i u mnogim ekavskim čakavskim govorima (VRANIĆ 2005: 183-191), a tako je redovito u svim dijelovima temporala (VRANIĆ 2018: 255), pa i u ovdje analiziranim: v'sobotu (107ra), v sobotu (120ra), soboti $(165 \mathrm{vc}), v$ sobotu $(237 \mathrm{vd}) . \mathrm{S}$ druge strane, slogotvorno $l$, u govoru Berma dosljedno zamijenjeno vokalom $u$ (vuna, sunce, suza, puž, vuk), neizmijenjeno je u cijelom temporalu, pa i u ovom korpusu (slzi 106rb, 174ra, slzami 107vc, isplni 177rb, plnu 178ra, isplnite 239vc itd.) i pokazuje povezanost sa staroslavenskom tradicijom (VRANA 1951: 129.; DAMJANOVIĆ 2011: 287). 
Vodeći se metodologijom dijakronijske dijalektologije, uzimajući u obzir distribuciju u suvremenim pazinskim (i u ostalim skupinama središnjega istarskoga poddijalekta ekavskoga dijalekta čakavskoga narječja), jednako se tako može pretpostaviti da je primarni refleks u beramskomu govoru bio $o$ (g) (danas dosljedan u gramatičkim morfemima, a uz $u$ leksičkim u koje inovacije brže prodiru), a da je u ovom temporalu $u$ ( $\boxplus$ ) bilježen ponajprije prema normi hrvatskoga crkvenoslavenskoga jezika. U tom bi se smjeru i unesene zamjene s $O$ (g) - to više što je i na nekoliko primjera u sanktoralu $\mathrm{BrBer}_{2}$ upozorio M. Mihaljević (MIHALJEVIĆ 2011: 131) - možda mogle promatrati i kao utjecaj organskoga idioma.

\subsection{Prefiks *vy}

Prefiks * $v y$, nakon promjene $y($ ğp , gg $)>i(8)$ poznat kao arhaizam još u kanonskim starocrkvenoslavenskim tekstovima, ${ }^{30}$ zadržan je i u hrvatskoglagoljskim tekstovima, ali i u organskim idiomima sjevernočakavskoga područja. Tako je u govoru Berma, danas usporedo s likovima s prefiksom $z-($ 如-): vilest, vihitat, vibrat, ali i zbrat, spejat, zbos. Ranije je taj prefiks zasigurno bio zastupljeniji u organskim idiomima, što je doprinijelo i njegovu duljemu održanju u hrvatskim crkvenoslavenskim tekstovima (MIHALJEVIĆ 1997: 123). Bilježen je u svim dijelovima temporala, pa i u ovomu korpusu: ${ }^{31}$ vihititi $(118 \mathrm{vd})$, vihiceni $(165 \mathrm{ra})^{32}$ i potvrđuje pripadnost temporala sjevernočakavskomu arealu.

${ }^{30}$ Fonem $y$ (jeri: ğgP, gg8) na hrvatskom je području »izgubljen najkasnije do početka 12 . st.« (MIHALJEVIĆ 2018: 16).

${ }^{31}$ Jednako je i izvan korpusa: vihititi (132ra, 124rb, 135ra, 140vd, 144rb, 205ra, 206ra), vistupaetb (233ra), visprostriti (234vd).

${ }^{32} \mathrm{U}$ temporalu se i neke druge sjeverozapadne čakavske značajke nalaze u tragovima. Tako je u instrumentalu jednine imenskih riječi uz gramatički morfem -oju/-eju

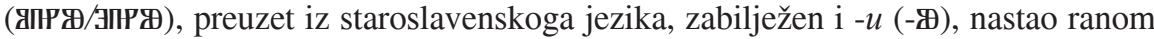
kontrakcijom -oio (-gogł), koji povezuje sjeverozapadnu čakavštinu, zapadnu kajkavštinu i slovenske govore (LUKEŽIĆ 1998: 149-150): nad' sobu (174vc), s tobu (211ra). No, za temporal ovoga brevijara nije tipična mijena koja bi se mogla očekivati: neutralizacija $o$ i $u$ (izuzev u $u(t) c u$ 195rb). Zamjene su tih vokala, naime, svojstvene i zapadnim govorima sjeverozapadnoga čakavskog areala, a na području Istre, čini se, najviše buzetskim govorima. Danas su sporadično ovjerene i u suvremenom govoru Berma (prednaglasno kratko o (马) $>u$ (刃): ureh, utroki/otroki, ubolijo 3. 1. mn. prez., udebelit, ufiendi jd. m. r. glag. prid. rad., ugənj, ali okuoli, oni, lonac). Potvrđene su i u liturgijskim i u pravnim rukopisima s buzetskoga područja: u $A k a-$ demijinu brevijaru iz 14. st., Greblovu Tlmačeniju od muki gospoda našego Isuhrsta, 


\section{ZAKLJUČAK}

Iako se s gledišta povijesne dijalektologije temporal Drugoga beramskoga (ljubljanskoga) brevijara $\left(\mathrm{BrBer}_{2}\right.$ ) prema jezičnim značajkama zastupljenim na prvih pedeset listova ne može atribuirati području Berma, u dijelovima je analiziranim za potrebe ovoga rada distribucija ključnih značajki ipak ponešto drukčija. Kasniji dijelovi temporala naime pokazuju jače previranje. Među jezičnim činjenicama uspoređenim s rezultatima istraživanja beramskoga govora provedenoga za ovaj rad dvije su temeljne: odrazjata (B) u gramatičkim morfemima i odraz stražnjega nazala osъ (got). Uvećani je broj tzv. ekavizama u prvim dvama za ovaj članak analiziranim dijelovima zasigurno posljedica tendencije da se ekavski odraz jata (B) piše slobodnije, odnosno percepcije jata (B) kao vokala e-tipa (DAMJANOVIĆ 2011: 284-285), ali moguće i utjecaja beramskoga govora, to više što se ekavske zamjene nalaze i u nekolikim gramatičkim morfemima. Ikavizmi u leksičkim morfemima, uz primjer zamjenice $\breve{c}$ (解), što je posvjedočen i u analizi provedenoj na fragmentu sanktorala $\operatorname{BrBer}_{2}$ (MIHALJEVIĆ 2011: 133), upućuju na predložak iz središta krčko-istarskih kodeksa, omišaljsko-vrbničkoga tipa govora. Kada je riječ o odrazu stražnjega nazala $Q S ъ$ (ğt), može se pretpostaviti da je prvotni refleks u beramskomu govoru bio $o$ (g) (danas dosljedan u gramatičkim morfemima, paralelan $\mathrm{s} u$ (刃) u leksičkim, u koje inovacije brže prodiru), a da je u ovom temporalu $u(\boxplus)$ bilježen primarno prema normi hrvatskoga crkvenoslavenskoga jezika. U tom bi se smjeru i rijetke zamjene s $o$ (g) - to više što je već i na nekoliko takvih primjera u sanktoralu BrBer $_{2}$ upozorio M. Mihaljević (2011: 131) - možda mogle promatrati ne samo kao slučajna pogreška pisara, odnosno grafijska zamjena $u$ (刃) sa $o$ (g), već i kao utjecaj organskoga idioma. Pomlađivanje teksta refleksom $j(\Pi \mathrm{IP})<* d j(* \Pi \mathrm{\|} \Pi \mathrm{H})$, zamijećeno od 38. do 50. lista, razvidno je i u ovom korpusu bez obzira na i dalje izrazitu brojnost

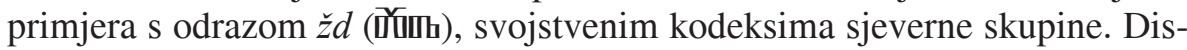
tribucija promjene prednjega nazala $\mathrm{u} a(\mathrm{~h})$ nije posebnost samo analiziranoga temporala, ali je uglavnom podudarna i s primjerima zabilježenim u govoru Berma, a kao i ranije analizirani dijelovi pridružuje ovaj brevijar sjevernomu tipu kodeksa i potvrđuje da hrvatski crkvenoslavenski jezik »ima više glasovnih promjena koje su zajedničke sa starohrvatskim jezikom, najvećim dijelom s čakavskim narječjem « (MIHALJEVIĆ 2014: 78). Ostali analizirani elementi ili su općečakavski (začb/zač’, prijedlog i prefiks $v a(-)$ (П巾) ispred vokala prednjega niza) ili su odraz starine (prefiks vi- (ПШ⿱-口))).

u glagoljskom notarskom protokolu iz Draguća 1595. - 1639. g. itd. S. Zubčić stoga neutralizaciju u tim govorima tumači postojanjem glasa $o$ zatvorene artikulacije u prednaglasnom slogu još u prvoj polovici 17. st. (ZUBČIĆ 2010: 642). 


\section{IZVOR:}

BADURINA STIPČEVIĆ, V.; I. BOTICA; M. DIMITROVA; M. DÜRRIGL; I. HRISTOVA ŠOMOVA; A. KOVAČEVIĆ; K. KUHAR; M. MIHALJEVIĆ; LJ. MOKROVIĆ; S. POŽAR; A. RADOŠEVIĆ; M. ŠIMIĆ; J. VELA; J. VINCE; J. VUČKOVIĆ; S. ZUBČIĆ; M. ŽAGAR. 2015. Preslovljeni Temporal Drugoga beramskog (ljubljanskog) brevijara. Zagreb: Staroslavenski institut. URL: https://beram.stin.hr/hr/transliteration/53 (10. 4. 2019.)

\section{KRATICA IZVORA}

$\mathrm{BrBer}_{2}-$ II. beramski brevijar, Ljubljana, Narodna in univerzitetna knjižnica, Ms 163, 15. st.

\section{LITERATURA}

BELIĆ, A. 1912. Izveštaj Državnom Savetu o pribiranju dijalektološke građe, potpomognutom sredstvima iz »Velimirijanuma«. Godišnjak SKA 26, 221-259.

BLAŽEVIĆ KREZIĆ, V. 2016. Jezik Misala Dragutina Antuna Parčića. Doktorska disertacija u rukopisu. Zagreb: Filozofski fakultet Sveučilišta u Zagrebu.

BROZOVIĆ, D. 1973. O hrvatskom književnom jeziku 16. st. Zbornik Zagrebačke slavističke škole 1, 129-135.

BROZOVIĆ, D. 1988. Čakavsko narječje. Brozović, D.; P. Ivić, Jezik srpskohrvatski / hrvatskosrpski, hrvatski ili srpski. Zagreb: JLZ »Miroslav Krleža«, 80-90.

DAMJANOVIĆ, S. 2011. Jezik hrvatskih glagoljičnih tekstova. R. Katičić; J. Lisac (ur.). Povijest hrvatskoga jezika. 2 knjiga: 16. st. Zagreb: Društvo za promicanje hrvatske kulture i znanosti CROATICA, 275-322.

DAMJANOVIĆ, S.; I. JURČEVIĆ; T. KUŠTOVIĆ; B. KUZMIĆ; M. LUKIĆ; M. ŽAGAR. 2004. Mali staroslavensko-hrvatski rječnik. Zagreb: Matica hrvatska.

HORVAT, M. 2005. Crkvenoslavenski elementi u starohrvatskim oporukama. S. Damjanović (ur.). Drugi Hercigonjin zbornik. Zagreb: Hrvatska sveučilišna naklada, $145-158$.

IVIĆ, P. 1961. Prilozi poznavanju dijalekatske slike zapadne Hrvatske. Godišnjak Filozofskog fakulteta u Novom Sadu 6, 191-212.

KALSBEEK, J. 1983. Prilog proučavanju vokalnih sustava sjeverozapadnočakavskih govora u Istri. Dutch Contributions to the Ninth International Congress of Slavists (Studies in Slavic and General Linguistics 3), 24-7264.

KAPETANOVIĆ, A. 2011. Čakavski hrvatski književni jezik. R. Katičić; J. Lisac (ur.). Povijest hrvatskoga jezika. 2 knjiga: 16. st. Zagreb: Društvo za promicanje hrvatske kulture i znanosti CROATICA, 77-124. 
KAPETANOVIĆ, A. 2016. Jezik u starim versima hrvatskim. Split: Književni krug.

KUZMIĆ, B. 2009. Jezik hrvatskih srednjovjekovnih pravnih spomenika. S. Damjanović (ur.). Povijest hrvatskoga jezika. 1 knjiga: srednji vijek. Zagreb: Društvo za promicanje hrvatske kulture i znanosti CROATICA, 405-455.

KUZMIĆ, B. 2011. Jezik hrvatskih pravnih tekstova. R. Katičić; J. Lisac (ur.). Povijest hrvatskoga jezika. 2 knjiga: 16. st. Zagreb: Društvo za promicanje hrvatske kulture i znanosti CROATICA, 323-386.

LISAC, J. 2009. Hrvatska dijalektologija 2. Čakavsko narječje. Zagreb: Golden marketing - Tehnička knjiga.

LUKEŽIĆ, I. 1990. Čakavski ikavsko-ekavski dijalekt. Rijeka: Izdavački centar Rijeka.

LUKEŽIĆ, I. 1998. Govori Klane i Studene. Crikvenica: Libellus: Knjižnica/Analize, portreti, studije, Drugo kolo/knjiga I.

LUKEŽIĆ, I. 2005. Jezik grobničke brašćinske knjige (16. i 17. stoljeće) kao dijalektološki predložak. S. Damjanović (ur.). Drugi Hercigonjin zbornik. Zagreb: Hrvatska sveučilišna naklada, 223-246.

LUKEŽIĆ, I. 2012. Zajednička povijest hrvatskih narječja. 1. Fonologija. Zagreb: Hrvatska sveučilišna naklada - Filozofski fakultet u Rijeci - Katedra Cakavskoga sabora Grobnišćine.

LUKEŽIĆ, I. 2015. Zajednička povijest hrvatskih narječja. 2. Morfologija. Zagreb: Hrvatska sveučilišna naklada - Filozofski fakultet u Rijeci - Katedra Cakavskoga sabora Grobnišćine.

LUKEŽIĆ, I.; M. TURK. 1998. Govori otoka Krka. Crikvenica: Libellus.

MALIĆ, D. 1991. Samoglasničke pojave u »Žićima svetih otaca«. Rasprave Zavoda za hrvatski jezik 17, 83-122.

MAŁECKI, M. 1930. Przegląd słowiańskich gwar Istrji. Prace Komisji językowej 17. Kraków: Polska Akademja umiejętności, 1-160.

MATASOVIĆ, R. 2008. Poredbenopovijesna gramatika hrvatskoga jezika. Zagreb: Matica hrvatska.

MIHALJEVIĆ, M. 1997. Jezična slojevitost Brevijara Vida Omišljanina iz 1396. godine. Filologija 29, 119-138.

MIHALJEVIĆ, M. 2009. Hrvatski crkvenoslavenski jezik. S. Damjanović (ur.). Povijest hrvatskoga jezika. 1 knjiga: srednji vijek. Zagreb: Društvo za promicanje hrvatske kulture i znanosti CROATICA, 283-349.

MIHALJEVIĆ, M. 2011. Bilješke o jeziku Drugoga beramskoga brevijara. Tabula 9, 126-139.

MIHALJEVIĆ, M. 2014. Uvod; Pismo i fonemski sustav; Zamjenice. M. Mihaljević; A. Šikić (ur.). Hrvatski crkvenoslavenski jezik. Zagreb: Hrvatska sveučilišna naklada - Staroslavenski institut, 9-22, 49-90, 133-150.

MIHALJEVIĆ, M. 2018. Jezik najstarijih hrvatskoglagoljskih rukopisa. Zagreb: Hrvatska sveučilišna naklada - Staroslavenski institut.

MOGUŠ, M. 1969. Jezični elementi Držićeva »Dunda Maroja«. N. Batušić; D. Fališevac (ur.). Zbornik radova o Marinu Držiću. Zagreb: Hrvatska akademija znanosti i umjetnosti, 269-281. 
MOGUŠ, M. 1977. Čakavsko narječje. Fonologija. Zagreb: Školska knjiga.

PANTELIĆ, M. 1964. Glagoljski kodeksi Bartola Krbavca. Radovi staroslavenskog instituta 5, 5-98.

PLIŠKO, L. 2003. Mjesni govor Berma. G. Labinjan (ur.). Beram u prošlosti (radovi sa Stručno-znanstvenog skupa o prošlosti Berma i okolice održanog u rujnu 2000. godine i naknadno prikupljeni), Pazinski memorijal 25. Pazin: Katedra Čakavskoga sabora za povijest Istre, 279-295.

POŽAR, S. 2014. Pridjevi. M. Mihaljević; A. Šikić (ur.). Hrvatski crkvenoslavenski jezik. Zagreb: Hrvatska sveučilišna naklada - Staroslavenski institut,151-188.

RIBARIĆ, J. 1940. Razmještaj južnoslovenskih dijalekata na poluotoku Istri. Srpski dijalektološki zbornik 9, 1-207.

ŠIMUNOVIĆ, P. 1985. Mozaik istarskih govora. Istra 3/4, 66-73.

ŠIMUNOVIĆ, P. 2011. Čakavska čitanka. Zagreb: Golden marketing - Tehnička knjiga.

TANDARIĆ, J. 1960. Osobine krčkih glagoljskih liturgijskih kodeksa. Croatica Christiana periodica 4, 6, 136-140.

UJČIĆ, R. 1985. O jednoj dijalektološkoj zabludi pri određivanju granica starosjedilačkoga govora pazinsko-žminjskoga dijalekta. Istra 3/4, 73-90.

VAJS, J. 1910. Nejstarši breviář chrvatsko-hlaholský. Praha: Nákl. Král. české společnosti náuk.

VERMEER, W. 1982. On the principal sources for the study of Čakavian dialects with neocircumflex in adjectives and $e$ presents. Studies in Slavic and Geral Linguistics 2, 279-340.

VINCE, J. 2014. Imenice. M. Mihaljević; A. Šikić (ur.). Hrvatski crkvenoslavenski jezik. Zagreb: Hrvatska sveučilišna naklada - Staroslavenski institut, 91-132.

VRANA, J. 1951. Hrvatskoglagoljski blagdanar. Rad JAZU 285, 95-179.

VRANIĆ, S. 2005. Čakavski ekavski dijalekt: sustav i podsustavi. Rijeka: Filozofski fakultet u Rijeci - Katedra Čakavskoga sabora Kostrena.

VRANIĆ, S. 2018. Neke dijalektne značajke u Drugom beramskom (ljubljanskom) brevijaru (na primjeru prvoga dijela Temporala). M. Mujić; I. Palić (ur.). Sarajevski filološki susreti 4: Zbornik radova (knjiga 1). Sarajevo: Bosansko filološko društvo, 245-259.

VRANIĆ, S.; S. ZUBČIĆ. 2013. Dialects in and around small urban centres in the northern Čakavian area. The current situation. A. Peti-Stantić; M. Stanojević; G. Antunović (ur.). Language Varieties Between Norms and Attitudes. South Slavic Perspectives. Proceedings from the 2013 CALS Conference. Frankfurt am Main: Peter Lang Edition, 49-68.

ZUBČIĆ, S. 2006. Akcenatski tipovi imenica i glagola u sjeverozapadnim čakavskim govorima (sinkronijski i dijakronijski aspekt). Doktorska disertacija u rukopisu. Rijeka: Filozofski fakultet.

ZUBČIĆ, S. 2010. Jezične značajke Greblova Tlmačenja od muki gospoda našego Isuhrsta (prilog dijakronijskoj dijalektologiji). L. Badurina; D. Bačić-Karković (ur.). Riječki filološki dani 8. Rijeka: Filozofski fakultet Sveučilišta u Rijeci, 631-646. 
ZUBČIĆ, S. 2014. Cakavizam u Rijeci (prilog dijakronijskoj dijalektologiji). Etymologica diachronica Slavica, w 75. Rocznicę urodzin Profesora Wiestawa Borysia. Warszawa: Instytut Sławistycna, 459-474.

ZUBČIĆ, S. 2015. Hrvatskoglagoljski tekstovi kao izvor podataka za povijesnu dijalektologiju hrvatskoga jezika. Croatica 59, 95-106.

ZUBČIĆ, S. 2017. Neocirkumfleks u čakavskom narječju, Rijeka: Sveučilište u Rijeci, Filozofski fakultet.

\title{
Sum mary
}

Silvana Vranić

\section{LINGUISTIC CHARACTERISTICS OF THE TEMPORAL OF THE SECOND BERAM (LJUBLJANA) BREVIARY FROM THE PERSPECTIVE OF HISTORICAL DIALECTOLOGY}

The focus of the paper is on the linguistic characteristics of the Temporal of the Second Beram (Ljubljana) Breviary $\left(\mathrm{BrBer}_{2}\right)$ that differ from the Old Church Slavonic characteristics and that could be attributed to the vernacular. Efforts to identify vernacular elements in the first 50 folios from the perspective of diachronic dialectology indicate that this part of the Temporal belongs to the northern type of liturgical texts. By taking into account the reliability, or lack thereof, of old texts as dialectological templates, the same methodology was applied to other parts of the temporal $(104 \mathrm{vd}-122 \mathrm{vd}, 165 \mathrm{ra}-194 \mathrm{vd}$ i $237 \mathrm{ra}-240 \mathrm{vd})$ that were singled out by Žagar on the basis of the primary impression of the script (proportions of the letters, position within the line) in other to verify the presence of vernacular elements. Those linguistic characteristics were then compared to the results of the research into the idiom of Beram with the aim of determining whether Temporal I was written by scribes whose mother idiom was of the Beram type or whether the scribes had simply introduced elements of this type into the text. Among the identified linguistic characteristics two seem to be fundamental: the reflex of yat (B) in grammatical morphemes and the reflex of the posterior nasal. An increased number of Ekavisms in the first two parts is a consequence of the tendency to note down the Ekavian reflex of yat $(\boldsymbol{B})$ more freely, i.e. of the perception of yat (B) as an $e$-type vowel, but it could also be a result of the influence of the idiom of Beram. This seems to be supported by the fact that the Ekavian replacements of yat (B) are also present in grammatical morphemes. Ikavisams in lexical morphemes seem to support the notion that the template for the Second Beram (Ljubljana) Breviary originated in the Krk area. With regard to the reflex of the posterior nasal, although rare, the replacements by $o$ - in the context of those examples in the Sanctoral of this Breviary indicated by Mihaljević - could possibly also be seen as a result of the influence of the organic idiom.

Keywords: Second Beram (Ljubljana) Breviary, Temporal, vernacular, idiom of Beram, Croatian Old Church Slavonic, historical dialectology

\author{
Silvana Vranić \\ Faculty of Humanities and Social Sciences in Rijeka \\ Rijeka (Croatia) \\ silvana.vranic@uniri.hr
}

